\title{
Correction to: New Public Management and Economic Feasibility Assessment of PPP Projects. A Case Study in Calabria
}

Francesco Calabrò, Lucia Della Spina, and Basiliana Randò

\section{Correction to:}

Chapter "New Public Management and Economic Feasibility Assessment of PPP Projects. A Case Study in Calabria" in: P. Morano et al. (eds.), Appraisal and Valuation, Green Energy and Technology, https://doi.org/10.1007/978-3-030-49579-4_5

In the original version of the book, the chapter author name "Lucia Della Spina" was published with incorrect given name and family name. The chapter and book have been updated with the changes. 